\title{
非ガウス型量子状態の生成について
}

\author{
和久井 健太郎 † \\ (独) 情報通信研究機構 光波量子・ミリ波ICTグループ（テ 184-8795 東京都小金井市貫井北町4-2-1）
}

\section{Generation of Non-Gaussian Quantum State of Light}

\author{
Kentaro WAKUI ${ }^{\dagger}$ \\ Advanced Communications Technology Group, National Institute of Information and Communications Technology (NICT), \\ 4-2-1 Nukui-kitamachi, Koganei, Tokyo 184-8795
}

(Received February 22, 2008)

\begin{abstract}
We present generation of photon-subtracted squeezed state at $860 \mathrm{~nm}$, from continuous-wave squeezed vacua generated with a periodically-poled $\mathrm{KTiOPO}_{4}$ crystal as a nonlinear medium of a subthreshold optical parametric oscillator. We observe various kinds of photon-subtracted squeezed states, including "non-Gaussian" states similar to the single-photon state and superposition states of coherent states, simply by changing the pump power. Nonclassicality of the generated states clearly emerges as its negative region around the origin of the phase-space distributions, i.e., the Wigner functions. We obtain the value, -0.083 at the origin of the Wigner function, which is largest ever observed without any correction for experimental imperfections.
\end{abstract}

Key Words: Quantum optics, Quantum information, Squeezed state, Schrödinger cat state

1.はじめに

光を用いた量子情報処理は, 二つの領域に大別するこ とが可能である。その一つは, qubitを初めとする離散変 数が情報処理の担い手となった, 離散量量子情報処理で ある。ここでは光子の持つエネルギーの離散性が有効活 用されており, 現在の光量子情報処理の主流となってい る. 離散量量子情報処理については, 次号の小特集で系 統的な解説がなされる予定なので, そちらもぜひ参照さ れたい。そそし，もう一つが連続量量子情報処理であ $る^{1)}$. 連続量量子情報処理では, 光の直交位相成分と呼ば れる連続変数に情報を符号化するため, 光の波動性を積 極的に生かした領域であるといえる。

上記二つの領域における研究は, 同じ光という媒体を 用いていながら, 離散変数と連続変数という異なる基底 を情報処理に用いているという本質的な違いがある点 や，最適化されてきた実験技術の相違のために，これま で相互に乗り入れられることは乏しかった。 ところが世 紀の境目を皮切りに，これらの技術を同時に制御しよう とする試みが急速に広まってきている。

\section{1 光波制御}

まず連続量を用いた場合の量子情報処理の概要について 述べる. 連続量における情報処理では, 光の直交位相と呼 ばれる連続变数が情報処理の基底として用いられる. 光の 直交位相は, 量子化された電磁場の $\sin$ 成分, $\cos$ 成分であ り，これらは調和振動子の量子化にちなんで $X, P$ などと 書かれる。この連続量の量子情報処理で重要な役割を果た すのが，コヒーレント状態ならびに直交位相成分スクィー ズド状態(以下，単純に「スクィーズド状態」と呼ぶ)であ $ろ^{2)}$.

コヒーレント状態は良く定義された位相を持つ。このた め, コヒーレント状態は数ある光の量子状態のうちで最も 古典に近く, 連続的に発振したレーザー光(を十分弱めた 場合)の量子状態を表すのに用いられている。ただし, 最 も古典に近いとはいえ, コヒーレント状態は最小不確定状 態であり，量子摇らぎ成分という量子性を持つ。また，特 に連続量の分野において量子もつれを生成するために積極 的に活用されているのが，スクィーズド状態と呼ばれる非 古典状態である，スクィーズド状態も最小不確定状態であ るが，2次の非線形八ミルトニアンによって，特定の直交 位相成分においては量子摇らぎ成分までもが圧搾されてい る.このようなスクィーズド光は，しきい值以下で駆動さ

†現所属：(株)富士通研究所ナノテクノロジー研究センター（テ243-0197 神奈川県厚木市森の里若宮10-1）

${ }^{\dagger}$ Present affiliation: FUJITSU LABORATORIES LTD., 10-1 Morinosato-wakamiya, Atsugi, Kanagawa 243-0197 
れた光パラメトリック発振器 (Optical parametric oscillator: OPO）を用いて生成することができる．特にパルス光で は, パラメトリック増幅器 (Optical parametric amplifier: OPA)がスクィーザーとして用いられる.

ここで連続量の実験で用いられている技術について述 ベておきたい.コヒーレント光やスクィーズド光のよう に位相の良く定義された状態を検出するためには，エネ ルギーの測定のみでは不十分である。そこで，連続変数 である直交位相成分の測定には，ホモダイン測定と呼ば れる手法が用いられる。ホモダイン測定は干渉測定であ り, 微弱な信号光と非常に強い強度の局発光 (Local oscillator: LO)を分岐比が50: 50のビームスプリッタで干 渉させ, 各々の出力光を量子効率を平衡させたフォトダ イオードを用いて検出する．ホモダイン測定の量子力学 的解釈によれば，各々のフォトダイオードからの光電流 の差は, 純粋に直交位相成分をLOの強度で増幅したもの である。この平衡型ホモダイン測定には大きなメリット があり，近赤外の領域においては非常に高量子効率のシ リコンのpinフォトダイオード(量子効率〜1)を利用するこ とができるため，この波長領域における実験ではほぼ損 失の無い測定を行うことができる。

以上が光波制御における代表的なメリットであるが, 逆に性能的限界も指摘され始めている。これまで連続量 の実験で用いられてきた，スクィージング・ホモダイン 測定・ビームスプリッ夕・変位操作などは, 全て2次まで のハミルトニアンで形成される操作である：このような 操作で生成される状態は，2次までのモーメントによって 一意に記述できるため，ガウス型の量子操作として閉じ ていることが知られている3).このため，ガウス型量子操 作からさらなる高次の非線形性を引き出すことは不可能 であり，この性質にまつわる不可能定理の一例として，
連続量の量子もつれ抽出に関するものが知られている4). これは，伝送路の損失などのため部分的に壊れた連続量 量子もつれを, ガウス型量子操作によって回復させるこ とは出来ないというものである.

また, 現在の光通信の主役である $|\alpha\rangle$ のようなコーレ ント信号から, $|\alpha\rangle+|-\alpha\rangle$ のようコヒーレント信号の重 ねあわせを生成することも，ガウス型量子操作を用いる だけでは不可能である，このような重ね合わせは，光の 量子計算における計算スピードの劇的な向上6)や, 究極の 通信路容量7)の実現に必要不可欠であるため，ガウス型量 子操作のみを用いた従来技術を駆使するだけでは早晚, 光波制御は限界に達することが予想されるであろう。

\section{2 光子 · 光波同時制御〜光による量子計算に向け $\tau \sim$}

光波制御のほか光子制御までを含めた，光を用いた量 子情報処理の大まかな流れをFig. 1にまとめておく.

ところで, 離散量・連続量双方の領域において, 2000 年前後に光を用いた量子計算に関する重要な定理が示さ れている．本節では，それらを実現するための条件につ いて簡単に振り返りつつ, 前節までにおいて指摘した光 波制御の限界から，光子と光波を同時に制御する必要性 について解説したい.

1999年にLloyd とBraunsteinが示した提案によると，3次 かそれ以上の次数の非線形ハミルトニアンが用意できれ ば，任意の量子ゲートを生成することが可能である ${ }^{8)}$ 。こ れは直ちに，3次以上の非線形性をガウス操作と組み合わ せられれば量子計算が可能になる，ということを示して いる。3次以上の非線形操作は，しばしば「非ガウス型量 子操作」と呼ばれる。しかしながら, 文献8)で想定されて いる非ガウス型量子操作は, Kerr媒質のような非線形媒質

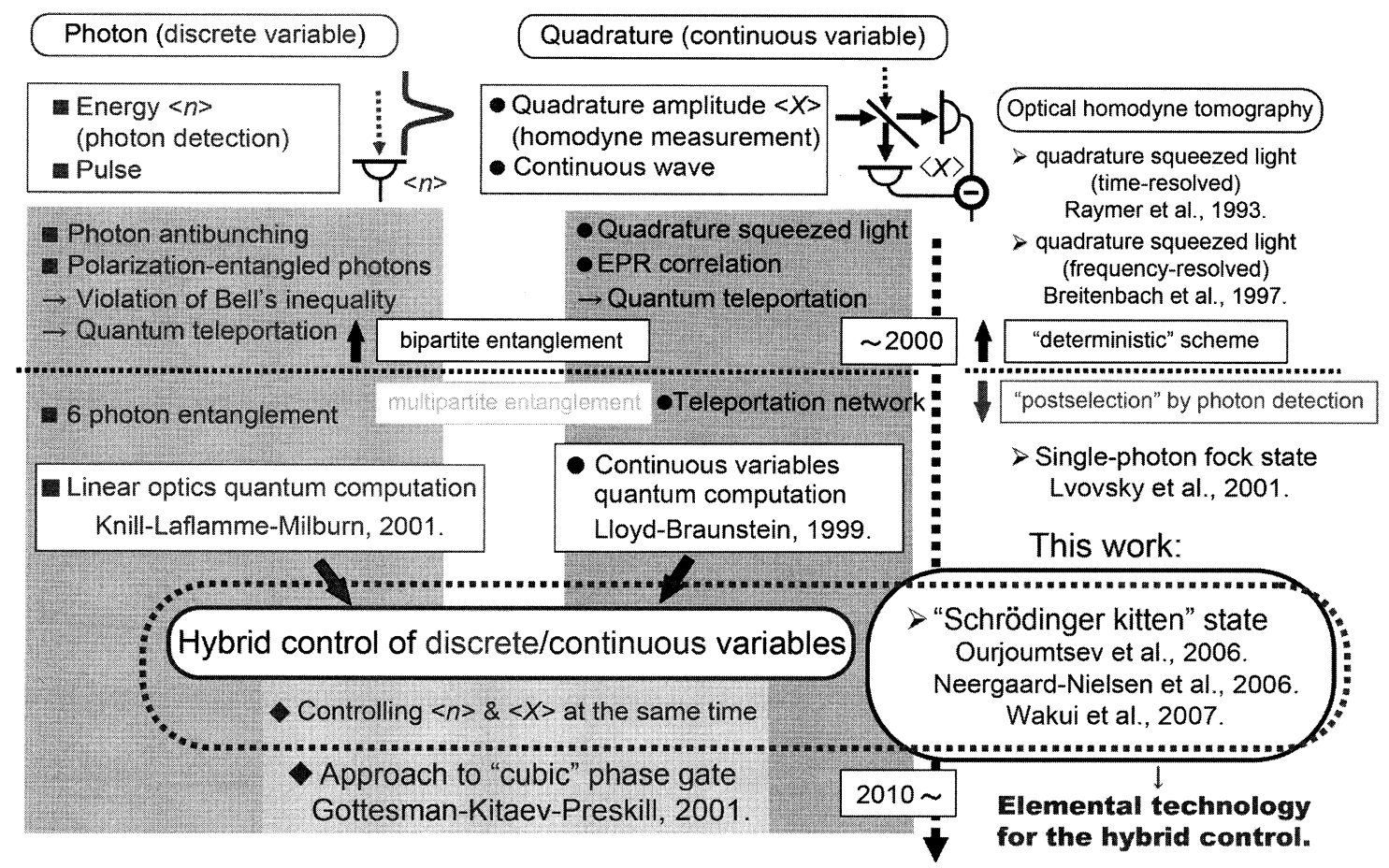

Fig. 1 A brief history of quantum information processing and quantum optics. 
によってようやく実現可能なものであり, 単一光子レベ ルの微弱な信号に対して適用できるような大きな非線形 性を持った光学媒質は，未だに知られていない†1。では， もし仮にそのような非線形性が利用できなかった場合に どうなるかといえば，2次までの非線形性のみを用いた場 合の連続量量子計算は，古典系で十分シミュレーション できる程度の性能しか発揮できないという結論が得られ ている5,6).

一方，離散量の領域に目を移すと，2001年にKnill， Laflamme, Milburnによって, 線形光学素子を用いた量子 計算という概念が発表された9)。この手法によれば，ビー ムスプリッタのような線形光学素子, 光子検出器, 補助 的な量子もつれを生成するための単一光子源を組み合わ せると，確率的に任意の量子ゲートを構築できる。ここ で重要になってくるのが，光子検出によって非線形性を 出そうとする試みであり，このような試みは一般に，「測 定誘起型非線形過程」と呼ばれている11).

測定誘起型非線形過程では, 量子もつれと光子検出器 の性質を用いて，実効的に強い非線形過程を誘起でき る。この過程を実現するための最も簡単な配置のうちの 一つを，以下のFig. 2に示す. Fig. 2では，まずスクィーズ ド状態のような入力量子状態がビームスプリッタで分割 され，もつれ合い状態が生成される，量子もつれはその 部分系が非局所的相関を持っているため，そのうちの片 方を光子検出器で測定すると，その測定結果に応じても う片方の量子状態が非局所的に変化するという効果が生 じる。ここで，光子数を識別する測定や光子の有無を判 別する測定は一般に光子数への射影測定となっており， この離散量への射影が非常に強い非線形性を誘起するた め, 残った状態は非線形な状態变化を受ける。この一連 の過程では, 光子検出器で測定した状態は壊れてしま い，またその操作自体も確率的なものであるというデメ リットがあるものの，単一光子レベルでの高次の非線形 性を実現できるため近年大きく注目されている。

ここまでの流れをまとめると，

・現在の技術では決定論的に実装できない非線形性を， 光子測定を用いて確率的に誘起する

・測定に際して壊れてしまう量子状態を補うために，あ

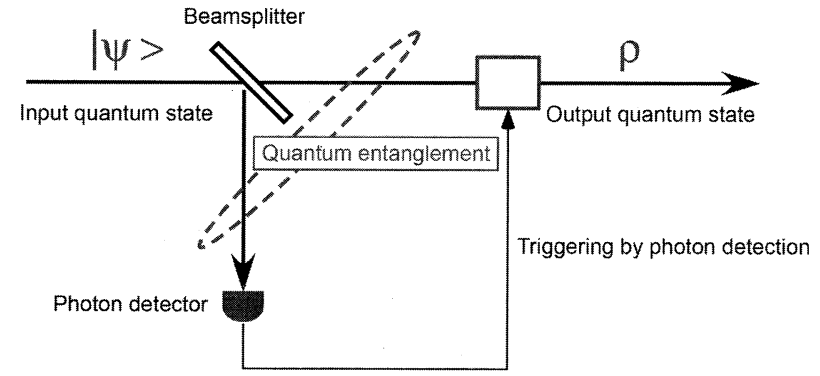

Fig. 2 An example of a measurement-induced nonlinear process.
らかじめ量子もつれ状態にある複数のモードを補助系と して準備しておく

という以上 2 点が，光の量子計算の実現に向けた試みの中 で，重要な役割を担っている.

これらの背景の中，Gottesmanらは連続量の系におい て, 従来のガウス操作に加えて光子検出を用いることに より，連続変数に量子ビットを符号化できることを示し た ${ }^{12)}$. 連続変数を2值の量子ビットに符号化する手続き は，極めて非線形な過程である。ここに，連続量を用い た量子情報処理においても，測定誘起型の非線形過程 が，高次の非線形性を誘起するために有効な手段である ことが示されたのである.

\section{2. 光の非ガウス型量子状態}

次に，前節までの流れと本論文の「非ガウス型量子状態 の生成」のつながりについて順に説明してゆきたい.

その前にまず，光の領域における巨視的重ね合わせ状 態について触れておく。ここでの巨視的重ね合わせ状態 とは，「マクロ」に識別可能なコヒーレント状態の重ね合わ せのことである。この「コヒーレント重ね合わせ状態」 (Coherent superposition state: CSS) は以下の式で記述され, 互いに位相が反転した二つのコヒーレント状態が，重ね 合わせ位相 $\varphi て ゙$ 重ね合わさっている，Nは規格化定数， $\alpha$ は コヒーレント振幅を表している.

$$
|\operatorname{cat}(\varphi, \alpha)\rangle=N\left\{|+\alpha\rangle+e^{i \varphi}|-\alpha\rangle\right\}
$$

コヒーレント状態が最も古典に近い状態であることは既 に触れたが，これらの重ね合わせ状態は，今度は極めて 量子性の高い状態となる。その最たる性質は，この状態 の持つ複雑な量子干渉の干渉縞である。コヒーレント状 態が最も古典的な量子状態であることから，これらの状 態はシュレーディンガーによって指摘された有名な猫の パラドクス ${ }^{13)}$ にちなんで，「シュレーディンガーの猫」状 態と呼ばれている14). 元々のシュレーディンガーの猫状 態は，古典的な事象の量子力学的重ね合わせを考えたと きに生じる不可思議さ(非古典性)を指摘したものであった が，このコヒーレント重ね合わせ状態も，電磁場の直交 位相成分の擬似確率分布関数 (Wigner関数, 後述)におい て“負の值”を持つ，という非古典性を示す。

このCSSの生成方法は，YurkeとStolerにより1986年に最 初の提案がなされた ${ }^{15)}$. ところが，この生成プロトコル もKerr効果のような3次の非線形を用いることを仮定して おり，物理的興味からその生成は積年の目標であったも のの，今に至るまでこの手法に即した成功例は光の領域 では報告されていない†2。 ところが，オリジナルの提案よ り10年ほど経ってから，CSSに非常に近い状態を生成でき る手法がDaknaらによって提案された16)。それが，本研究 で我々のグループで生成に成功した，スクィーズド状態

\footnotetext{
†1 現在までに有効なKerr効果を引き出せる系としてhigh-Q cavityを用いたcavity-QED系10)などが知られているが，これは高速の用途には 向かず，例えば光の進行波に作用させるような用途には不向きであろう.

†2マイクロ波領域や，捕獲イオンを用いた実験など，光以外の領域では既に成功例がある。
} 
から光子検出器を用いて光子を除去する手法である.

\section{1 シュレーディンガーの子猫状態}

以下のFig. 3に, Daknaらによって提案された手法を示 す.

このプロトコルは, 以下の通り極めてシンプルなもの である。

1) 光源にはガウス状態の一つであるスクイーズド状態を 入力として用意する

2)ビームスプリッタで分割した後, 片側の出力でAPDに よる光子検出を行う

3) 出力をホモダイン測定を用いて検証する

この手法でも先述の測定誘起型非線形過程の原理が活 用されており，補助的な量子もつれ生成のために，非古 典状態としてスクィーズド状態が用いられている。ス クィーズド状態をビームスプリッタで分割した際に生成 される量子もつれにより, 片方の出力で光子検出器を 行った結果, 出力量子状態は入力とは打って変わって, 形状の異なる「非ガウス型の量子状態」となる，この状態は その生成のメカニズムから,「光子を除去したスクィーズ ド状態 (photon-subtracted squeezed state: PSS)」と呼ばれて いる. 生成された状態の特性はWigner関数と呼ばれる擬 似確率分布で評価でき，これが大きな負の值を取るほど 非古典的性質が強いとされる. CSSもPSSもWigner関数の 值が負になる極めて非古典的な状態であり†3，それらの性 質がほぼ完全に一致する領域が存在する。CSS側から見た とき, PSSとのフィデリティが最も高くなるのが, CSSの

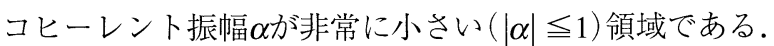
コヒーレント振幅がはっきりと識別可能なサイズとなる $|\alpha| \gg 1 の \operatorname{CSS}$ が，「巨視的」重ね合わせ状態とされるのに対 し， $|\alpha| \leqq 1 の 「$ 準巨視的」重ね合わせに対応するPSSは，し ばしば「シュレーディンガーの子猫」状態と呼ばれる。 Fig. 3では, PSSも, 比較に用いられているCSS $(\varphi=\pi)$ も, と もに奇数光子の重ね合わせ状態となっており, Wigner関
数の負の值はこの光子の奇のパリティに対応している.

このPSSは，実験的には縮退パラメトリック過程により 生成される真空スクィーズド光をビームスプリッタで分 割し，その出力のうち片方を APDを用いて光子検出する ことで生成可能である。もちろんAPDには本当の意味で の光子数識別能力はなく，光子の有無が判別できるだけ であるが，測定対象としている光が単一光子レベルの微 弱光であるため，APDを1個用いた場合には，近似的に単 一光子検出を行っていると見なすことができる．実際に 実験で用いている分岐比は，10\%ないしそれ以下程度の 反射率であり，そこから漏れて来たスクィーズド光の一 部を光子検出する，分岐比を上げると状態の生成確率は 増えるが，一方で出力状態も劣化するため，本質的には 小さい反射率とするのが妥当である.

このシンプルな手法においては，しかし一連の過程の 中に,

1. 状態の生成 : 光子検出器による離散的エネルギーの測 定

2. 状態の測定：ホモダイン測定による連続的位相分布の 測定

という離散量と連続量に関する重要な操作が含まれてい る。ここに，前節で述べてきた光子・光波同時制御との 大きなつながりが見出せる (Fig. 1)。つまり，Daknaらによ るPSS生成のプロトコルは，光の連続量量子計算などへ向 けた新しい技術開発のための，格好のたたき台となって いるのである。この新しい技術を実験的に開発すること が本研究の目的であり，本研究で開発した技術や，培っ たノウハウは今後，光を用いた量子情報処理の潜在能力 をさらに引き出すために, 必ずや役立つものになると言 えよう。

\section{2 最新の動向}

それでは，シュレディンガーの子猫状態の生成と，そ の周辺状況に関して述べていきたい.

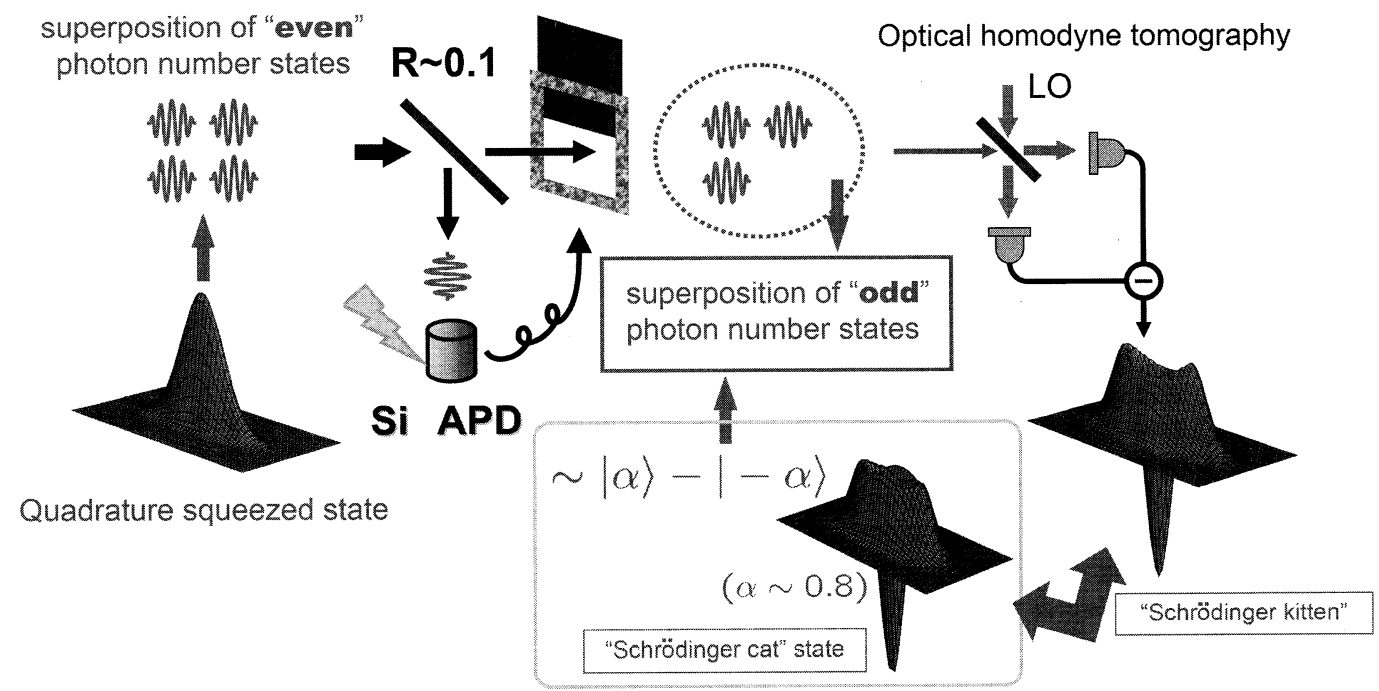

Fig. 3 The photon-subtraction scheme proposed by Dakna et al..

†3一方スクィーズド状態は非古典的状態であるが，ガウス型量子状態であり，Wigner関数は負の值を取らないことが知られている2). 
パルスのスクィーズド光とAPDを用いたPSS生成に関す る最初の試みは，2004年にフランス国立科学研究セン ター (Centre National de la Recherche Scientifique: CNRS)の グループから報告された17)。しかしながら，さまざまな 要因による損失のため，Wigner関数の負の值を実測する のは容易ではなく，この時点ではまだWigner関数に負の 部分は確認されなかった。実際には, 光子検出の結果,

入力のスクィーズド状態からの統計性の変化が確認され ただけであり，生成されたPSSのCSSとの類似性はそれほ ど高くはなかった。

ところが2006年になり，CSSに極めて近い性質 (=Wigner 関数の負の領域)を持ったPSSの生成成功に関する報告が 相次いだ。最初のグループはやはりCNRSのグループで, 次に続いたのがコペンハーゲン大学ニールスボーア研究 所 (Niels Bohr Institute: NBI)のグループであった ${ }^{18,19)}$. CNRSのグループでは光源としてフェムト秒のパルスレー ザーが用いられており, 光源はパルスのスクィージング である(波長 $850 \mathrm{~nm}$ 付近). フランスのグループの実験で生 成されたPSSは，もっとも大きい負の值を取るWigner関数 原点において, 実測值として $-0.026 \pm 0.012$ と明らかな負 の值が得られており, PSSがコヒーレント振幅の小さい CSSに極めて近い性質を持っていることが確認された。こ のため, 彼らの実験はシュレーディンガーの子猫状態に 関する最初の成功例であるとされている。一方NBIのグ ループでは波長852 nmにおける連続波のスクィーズド光
が用いられており，光源はリング型光共振器を用いた OPOである。こちらでも実測值でほんのわずかに負の值 が得られたとのことであったが，具体的な数值は掲載さ れていない。 逆に, ホモダイン検出器の量子効率などを 補正することにより - 0.040土0.014の值が示されている.

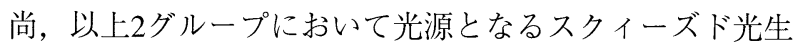
成に用いられていた非線形光学結晶は，二オブ酸カリウ ム $\left(\mathrm{KNbO}_{3}\right)$ であった。

我々のグループ(情報通信研究機構, 東京大学)におい ても，波長860 nmの連続波スクィーズド光を用いて2004 年から独自にこの状態の生成に取り組んできており，世 界初の原理実証が叶わなかったのは大変残念であった。 しかしながら，我々のグループでは系全体の損失を低く 抑える実験的努力に加え，二オブ酸カリウムとは異な る, 非常に低損失な非線形光学材料 (周期分極反転燐酸于 タン酸カリウム: PPKTP) を採用することにより，先行の2 研究と比較して大きな負の值 $(-0.081)$ を持った状態を, ほぼ同時期に観測することに成功した ${ }^{20)}$ 。これは無補正 の值としては世界記録である(単位系は いる†4). 以下のFig. 4に，PPKTPを用いてさまざまな励起 光領域で実験を行った結果を示す．図中 $a ， b ， c は$ はそぞ れ, $\mathrm{a} \rightarrow \mathrm{c}$ でOPOの励起光強度を大きくしていったときの Wigner関数である.Fig. 4中段はホモダイン測定結果から 得られる直交位相成分の実波形デー夕，下段が実波形 データを元に最尤推定法を用いて算出した密度行列の対

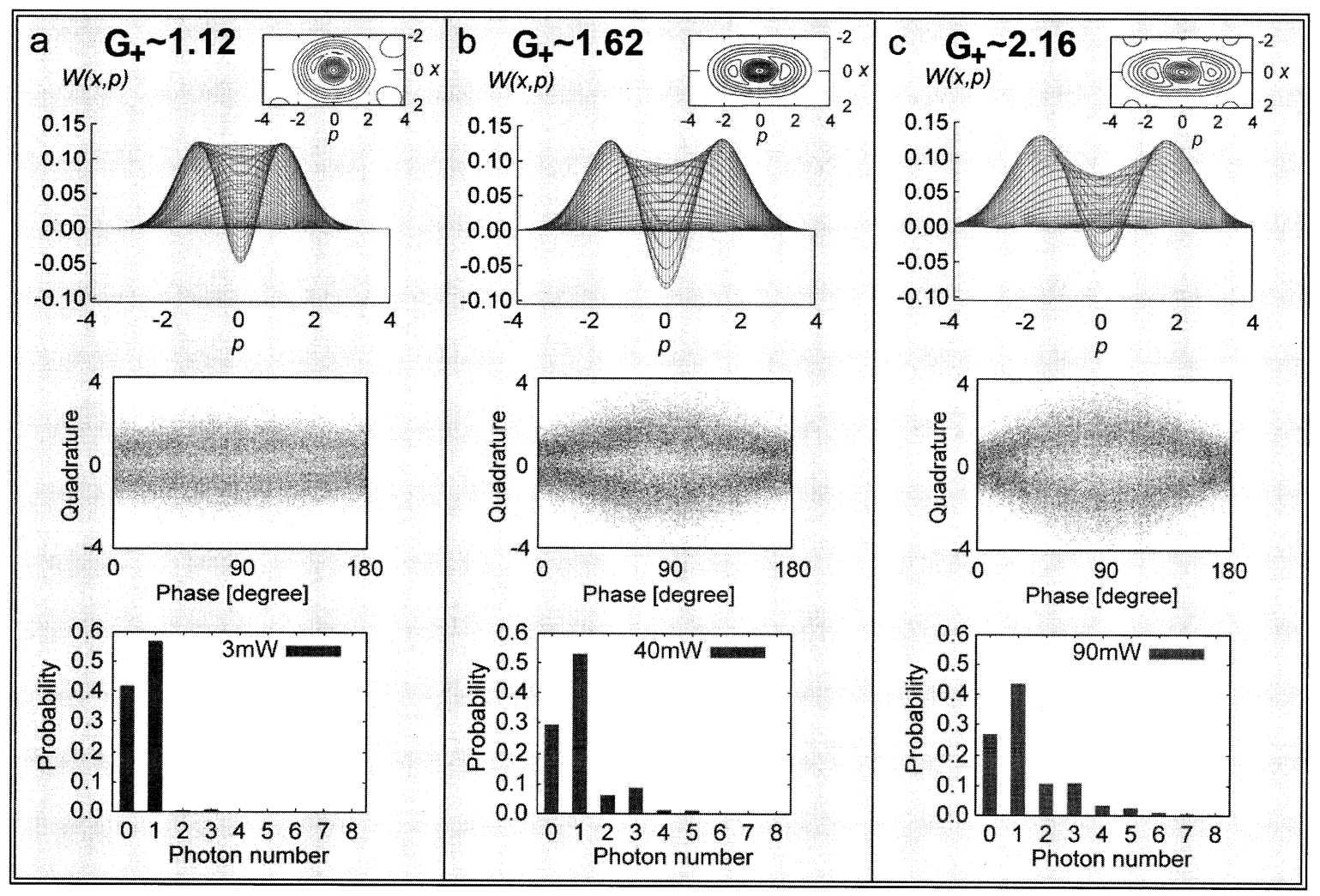

Fig. 4 Experimental results on 3 different pump regions: G+ are gain values of the subthreshold OPO.

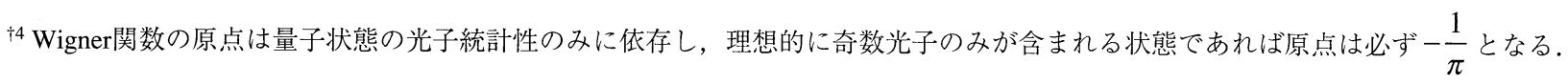


角項，上段が密度行列全体から計算したWigner関数であ る。ポンプ光強度が小さい領域では単一光子に近いが, ポンプ光強度が大きくなると二つのピークが徐々に識別 できるようになっている．尚，このときのAPD系への分 岐比は5\%である。

\section{3. 展 望}

CNRSグループの実験に関しては，子猫状態の生成実験 以降， $n=20$ 光子数状態のトモグラフィ実験 ${ }^{21)}$ ，またコ ヒーレントに干渉させた光子を除去する手法を用いた， 量子もつれ増幅の実験 ${ }^{22}$ が報告されている。さらに文 献23)では，2光子状態をホモダイン測定で事後選択する ことにより異なる猫状態を生成することに成功してお り，このような状態は最終的には量子中継器への応用が 見达まれている。また，文献22)のプロトコルが最終的に 目標とするところが連続量の量子もつれ抽出であること は明白であり，これは今現在，実験が待ち望まれている 連続量の最重要プロトコルのうちの一つである。

一方，CNRSのグループがパルス光を光源として用いて いるのに対し，我々のグループとNBIのグループは光共振 器で生成された連続波の光源を使用しており，その共振 器線幅はともに約 $10 \mathrm{MHz}$ 程度である。これは例えばセシ ウムD2線(波長 $852 \mathrm{~nm}$ )の線幅などに近い值であり，EIT等 の手法を用いた原子による量子メモリ24)への応用を見据 えた場合，パルスの実験にはない大きな利点があるとい える。また，光のFock状態に対応する状態として，原子 ではDicke状態が知られている。今回生成した光子のパリ ティの揃った光を，例えばDicke状態やその重ね合わせ状 態へ転写させる，といったことも将来的には可能になる かもしれない.

他には，例えば量子テレポーテーションにおいてこの ような状態を伝送しようと試みた際, 伝送路における損 失に打ち勝ち出力側でも負の部分を確認するためには, 入力としてできるだけ負の值の大きい状態が必要となろ う.今回我々のグループにおいて得られた負の值は, 実 験的な効率を考慮した場合の限界值に近く，非古典性を
伝送する際の強力な武器となることが期待される.

\section{参考文献}

1) S. L. Braunstein and A. K. Pati: Quantum Information with Continuous Variables (Kluwer Academic Publishers, Netherlands, 2003).

2) U. Leonhardt: Measuring the Quantum State of Light, (Cambridge University Press, Cambridge, 1997).

3) A. Ferraro, S. Olivares, and M. G. Paris: Gaussian states in quantum information (Biliopolis, Napoli, 2005).

4) J. Eisert, S. Scheel, and M. B. Plenio: Phys. Rev. Lett. 89 (2002) 137903; J. Fiurášek: Phys. Rev. Lett. 89 (2002) 137904; G. Giedke and I. Cirac: Phys. Rev. A. 66 (2002) 032316.

5) S. D. Bartlett, B. C. Sanders, S. L. Braunstein, and K. Nemoto: Phys. Rev. Lett. 88 (2002) 097904.

6) S. D. Bartlett and B. C. Sanders: Phys. Rev. Lett. 89 (2002) 207903

7) V. Giovannetti, S. Guha, S. Lloyd, L. Maccone, J. H. Shapiro, and H. P. Yuen: Phys. Rev. Lett. 92 (2004) 027902.

8) S. Lloyd and S. L. Braunstein: Phys. Rev. Lett. 82 (1999) 1784.

9) E. Knill, R. Laflamme, and G. J. Milburn: Nature 409 (2001) 46.

10) Q. A. Turchette, C. J. Hood, W. Lange, H. Mabuchi, and H. J. Kimble: Phys. Rev. Lett. 75 (1995) 4710.

11）佐々木 雅英，松岡 正浩 監修：量子情報通信（オプトロニク 又社, 2006年).

12) D. Gottesman, A. Kitaev, and J. Preskill: Phys. Rev. A 64 (2001) 012310.

13) E. Schrödinger: Naturwissenschaften 23 (1935) 807; 23 (1935) $823 ; 23$ (1935) 844

14) C. C. Gerry and P. L Knight: Introductory quantum optics, (Cambridge University Press, Cambridge, 2005).

15) B. Yurke and D. Stoler: Phys. Rev. Lett. 57 (1986) 13.

16) M. Dakna, T. Anhut, T. Opatrny, L. Knoll, and D.-G. Welsch: Phys. Rev. A 55 (1997) 3184.

17) J. Wenger, R. Tualle-Brouri, and Ph. Grangier: Phys. Rev. Lett. 92 (2004) 153601.

18) A. Ourjoumtsev, R. Tualle-Brouri, J. Laurat, and Ph. Grangier: Science 312 (2006) 83

19) J. S. Neergaard-Nielsen, B. Melholt Nielsen, C. Hettich, K. M lmer, and E. S. Polzik: Phys. Rev. Lett. 97 (2006) 083604

20) K. Wakui, H. Takahashi, A. Furusawa, and M. Sasaki: Opt. Express 15 (2007) 3568.

21) A. Ourjoumtsev, R. Tualle-Brouri, and Ph. Grangier: Phys. Rev. Lett. 96 (2006) 213601.

22) A. Ourjoumtsev, A. Dantan, R. Tualle-Brouri, and Ph. Grangier Phys. Rev. Lett. 98 (2007) 030502.

23) A. Ourjoumtsev, H. Jeong, R. Tualle-Brouri, and Ph. Grangier: Nature 448 (2007) 784

24) C. Monroe: Nature 416 (2002) 238.
シュレディンガーの猫状態 (Schrodinger cat state)

マクロスコピック(巨視的)に識別できる量子状態の, 重ね合わせ状態. 名称の由来は, シュレディンガーに よって1935年に提案された，量子力学の不可思議な点を 指摘した著名な思考実験(生きている猫と死んでいる猫の 重ねあわせ)である，現在に至るまで，シュレディンガー の提案そのもののような巨視的な系での重ね合わせは実
現していないものの，イオントラップを用いた捕獲原子 系や，超伝導を用いたマイクロ波共振器内など，準巨視 的と見なせる量子系に拈いては実現されている。今回紹 介した光の領域におけるシュレディンガーの猫状態は, 電磁波の位相が180度ずれた，振幅の小さな二つのコヒー レント状態の重ね合わせである。

(和久井 健太郎) 